\title{
Primary squamous cell carcinoma of Bartholin's gland diagnosed by fine needle aspiration cytology
}

\author{
Department of Obstetrics and Gynecology ${ }^{1)}$, Department of Pathology, Fukuoka Red Cross Hospital ${ }^{2}$, \\ Department of Obstetrics and Gynecology, Fukuoka Saiseikai Hospital ${ }^{3)}$ \\ Masashi Imachi ${ }^{1)}$ Yasuo Kato ${ }^{2)}$ Kuniaki Funakoshi ${ }^{3)}$
}

The cytologic and histologic findings in an extremely rare case of primary squamous cell carcinoma of Bartholin's gland are described. The tumor cells in fine needle aspiration smears were seen to be isolated or in clusters. The nuclei were round-to-oval, and uniform in shape and size. The chromatinic material was slightly increased. The tentative diagnosis was primary squamous cell carcinoma of Bartholin's gland, based on the cytologic findings and the location of the tumor. Similar findings were noted in the biopsy and surgical specimens. Fine needle aspiration smears have greater diagnostic value for a Bartholin's gland tumor.

Key words: Bartholin's gland-Fine needle aspiration cytology-Squamous cell carcinoma-Case report

\section{Introduction}

Primary carcinoma of Bartholin's gland accounts for only $2-7 \%$ of all vulvar cancers ${ }^{1 \sim 3)}$. In common histologic types of Bartholin's gland carcinoma such as squamous cell carcinoma, adenocarcinoma and adenoid cystic carcinoma, squamous cell carcinoma constitutes the most common frequency $30-75 \%{ }^{2,3)}$. The cytologic findings for Bartholin's gland car-

\footnotetext{
Primary squamous cell carcinoma of Bartholin's gland diagnosed by fine needle aspiration cytology Masashi IMACHI ${ }^{1)}$, M.D., Yasuo KATO ${ }^{2)}$, C.T., I.A.C., Kuniaki FUNAKOSHI ${ }^{3)}$, M.D.

${ }^{1)}$ Department of Obstetrics and Gynecology, ${ }^{2)}$ Department of Pathology, Fukuoka Red Cross Hospital

${ }^{3)}$ Department of Obstetrics and Gynecology, Fukuoka Saiseikai Hospital

論文別刷請求先：画812 福岡市東区馬出 3 の 1 の 1 九州大 学医学部婦人科学産科学教室 井町正士

平成 5 年 7 月 14 日受付

平成 5 年 9 月 3 日受理
}

cinoma have been reported in several papers ${ }^{4 \sim 8)}$. However, for squamous cell carcinomas, only one paper reported the cytologic findings in routine cervico-vaginal smears ${ }^{6}$. We describe below the first case of squamous cell carcinoma of Bartholin's gland which was initially diagnosed by fine needle aspiration cytology from a vulvar tumor.

\section{Case report}

A 60-year-old Japanese woman, gravida 4, para 2, was admitted to the hospital on April 6, 1992 with complaints of a mass and pain in the left inguinal region. Biopsy of the inguinal tumor was performed and diagnosed metastatic squamous cell carcinoma of unknown origin. Her past medical history was noncontributory.

Pelvic examination revealed a $3 \times 2 \times 2 \mathrm{~cm}$, irregular, solid mass in the left labium minus (Figure 1 ). The surface of the mass was completely covered 


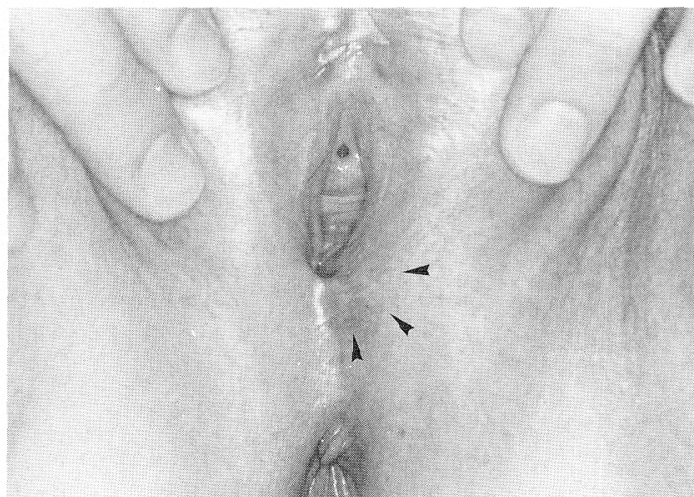

Figure 1 Squamous cell carcinoma of the left Bartholin's gland (arrows). The surface of the mass was covered with normal skin

with normal skin. The right inguinal lymph nodes were not palpable, and the left inguinal lymph nodes were unclear due to the induration after the biopsy. Routine cervico-vaginal smears were negative for malignant cells. Laboratory tests, chest roentgenograms, intravenous pyelogram, cystoscopy and sigmoidoscopy were all within normal limits. The value of SCC antigen was $1.5 \mathrm{ng} / \mathrm{m} l$.

Fine needle aspiration (FNA) smears from the vulvar mass were made, and numerous malignant squamous cells were identified. The pathology report on the biopsy specimens indicated squamous cell carcinoma. The patient underwent a radical vulvectomy with bilateral groin lymph node dissection on April 16, 1992. All the lymph nodes, except one which was resected previously, were negative for tumor metastasis, and the margin of the surgical specimen was negative for tumor cells. External radiotherapy to the left inguinal region and whole pelvis was administered. Fourteen months after surgery, the patient was well and free from signs of recurrence.

\section{Cytologic findings}

The FNA smears of the vulvar tumor contained many malignant squamous cells, isolated or in clusters. The background was clear. The nuclei were round-to-oval, enlarged and fairly uniform in size and shape (Figure 2). The chromatinic material

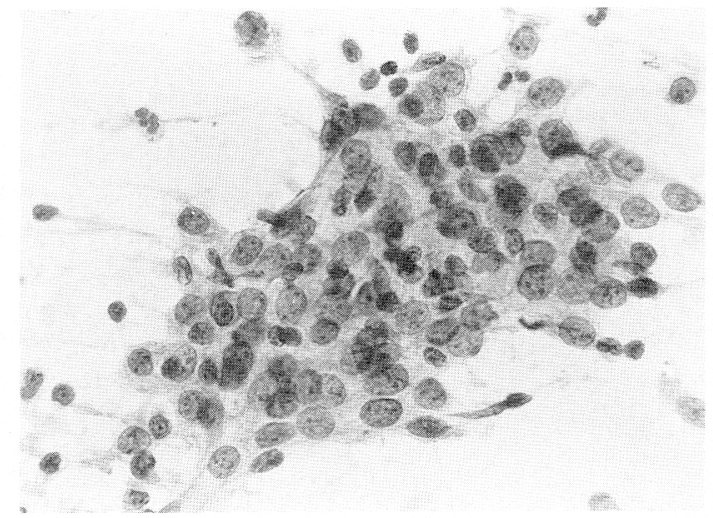

Figure 2 FNA cytology of the vulvar tumor. The nuclei are round-to-oval and the chromatin material is increased in amount and finely granular (Papanicolaou stain, $\times 40$ )

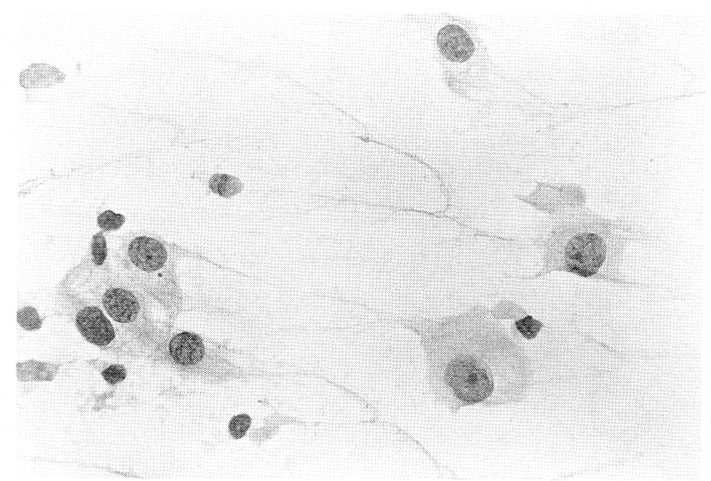

Figure 3 FNA cytology of the vulvar tumor showing tumor cells with thick and prominant cytoplasm (Papanicolaou stain, $\times 100$ )

was slightly increased in amount and finely granular. Nucleoli were prominent in some nuclei. There were some mitotic figures. The cytoplasm was thick and abundunt (Figure 3).

\section{Histologic findings}

Grossly, the tumor was located deeply in the labium minus and measured $3.0 \times 2.5 \times 2.5 \mathrm{~cm}$. The cut surface was solid, yellowish-white, and moist. Microscopically, a non-keratinizing squamous cell carcinoma was present beneath the normal squamous epithelium (Figures 4 and 5). The tumor cells infiltrated the fibrous stroma in clusters. Many 


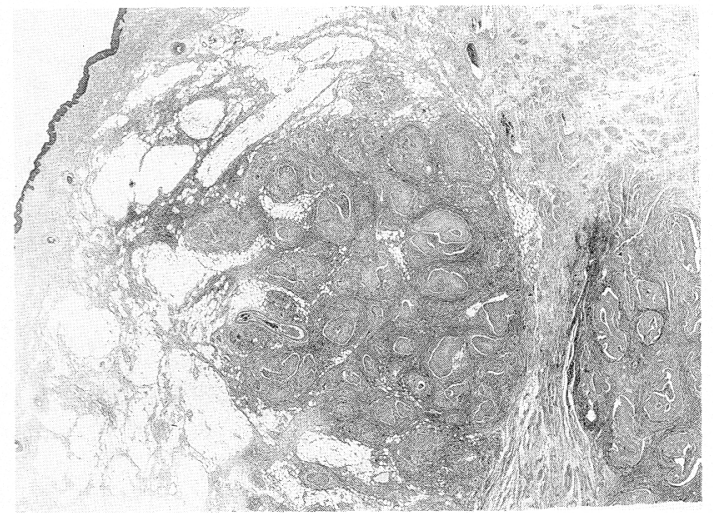

Figure 4 Low-power photomicrograph of the vulvar tumor showing a squamous cell carcinoma beneath the normal squamous epithelium (hematoxylin and eosin, $\times 4$ )

mitotic figures were present. Individual keratinization was observed in some tumor cells. Normal acini and ducts of Bartholin's gland were present next to the tumor. Mitotic figures were more numerous in the metastatic tumor in the inguinal lymph node than in the primary tumor. Moreover, nuclear atypia was more prominent in the metastatic lesion than in the primary lesion.

\section{Discussion}

Correct diagnosis of Bartholin's gland carcinoma is difficult. Chamlian and Taylor ${ }^{3)}$ reported that $50 \%$ of the patients $(12 / 24)$ with primary Bartholin's gland carcinoma were clinically misdiagnosed as a cyst or abscess. Dodson et al. ${ }^{1}$ recommended a routine cytologic evaluation at the time of marsupialization or drainage of a Bartholin's gland cyst. We also reported the diagnostic significance of FNA cytology in a patient with primary adenocarcinoma originating in a Bartholin's gland cyst? ${ }^{7}$. In patients with a Bartholin's gland tumor, FNA cytology is as diagnostically important as a biopsy. Moreover, a FNA smear is technically much easier to perform and less harmful to the patient than an open biopsy ${ }^{9,10)}$.

Squamous cell carcinoma is the most common histologic type of Bartholin's gland carcinomas.

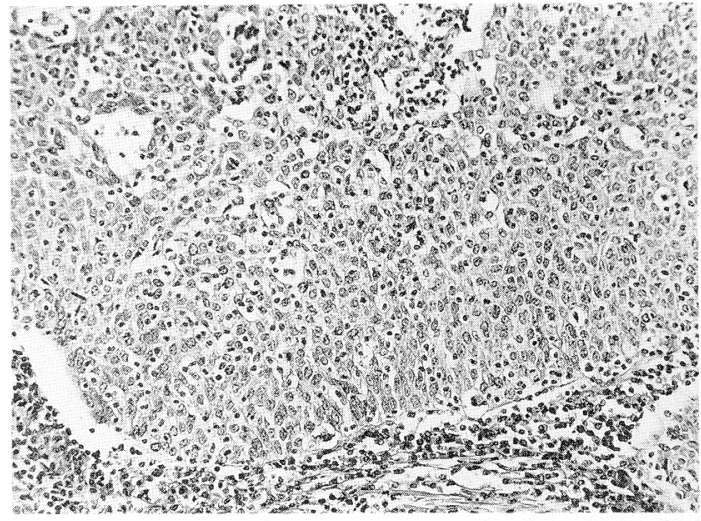

Figure 5 High-power photomicrograph of the vulvar tumor showing a squamous cell carcinoma (hematoxylin and eosin, $\times 20$ )

However, the cytologic findings for squamous cell carcinoma of Bartholin's gland have been reported in detail in only one paper on the basis of a routine cervico-vaginal smear ${ }^{6}$. Bartholin's gland tumors in their early stages do not reach the vulvar and/or vaginal surface epithelium. Thus, FNA smears have greater diagnostic value than routine genital smears $^{7)}$. In this case, the routine cervico-vaginal smears were negative for malignant cells.

Gupta et al. ${ }^{6}$ reported that spindle-shaped hyperchromatic cancer cells with abnormal nuclei were observed in a routine cervico-vaginal smear in a patient with well differentiated squamous cell carcinoma of Bartholin's gland. In our case, the tumor cells were fairly uniform in both size and shape. The cytologic findings suggested a poorly differentiated squamous cell carcinoma.

The location of the tumor is important in the diagnosis of a Bartholin's gland tumor. When clearly malignant cells are observed in a FNA cytology specimen in a patient with a Bartholin's gland tumor, an open biopsy need not be performed.

\section{要旨}

バルトリン腺扁平上皮癌の穿刺吸引細胞診における 細胞所見について報告した。腫瘍細胞の核は円形ない し楕円形で，クロマチンは微細顆粒状に増量し, 核小 体はやや目立った。細胞質は比較的豊富であった。こ 
のような細胞所見および腫瘤の解剖学的位置から, バ ルトリン腺原発の扁平上皮癌と診断した。バルトリン 腺の解剖学的位置を考慮すると, 穿刺吸引細胞診はバ ルトリン腺由来の腫瘍の診断方法として有用と考え る.

\section{References}

1) Dodson MG, O'Leary JA, Averette HE: Primary carcinoma of Bartholin's gland, Obstet Gynecol, 35 : 578 584, 1970.

2) Copeland LJ, Sneige N, Gershenson DM, et al. : Bartholin gland carcinoma, Obstet Gynecol, 67:794 801, 1986.

3) Chamlian DL, Taylor HB : Primary carcinoma of Bartholin's gland: A report of 24 patients, Obstet Gynecol, 39 : 489 494, 1972.

4) DeMauro JM, Skolom J, Wallach RC, et al. : Cytologic diagnosis of Bartholin's gland adenocarcinoma, Acta Cytol, 30: 491 493, 1986.
5) Frable WJ, Goplerud DR : Adenoid cystic carcinoma of Bartholin's gland. Diagnosis by aspiration biopsy, Acta Cytol, $19:$ 152 153, 1975.

6) Gupta RK, Belton JH, Bronowicz M : Cytologic diag. nosis of primary squamous cell carcinoma of Bartholin's gland, Acta Cytol, $21: 303 \sim 305,1977$.

7) Imachi $M$, Tsukamoto $N$, Shigematsu $T$, et al. : Cytologic diagnosis of primary adenocarcinoma of Bartholin's gland. A case report, Acta Cytol, $36: 167$ $\sim 170,1992$.

8) Naib ZM : Exfoliative cytology of a primary Bartholin's gland adenocarcinoma, Obstet Gynecol, 22 : 352 354, 1963.

9) Imachi M, Tsukamoto N, Shigematsu T, et al. : Fine needle aspiration cytology in patients with gynecologic malignancies, Gynecol Oncol, $46: 309 \sim$ 312, 1992.

10) Imachi $M$, Tsukamoto $N$, Kamura $T$, et al. : Alveolar rhabdomyosarcoma of the vulva. Report of two cases, Acta Cytol, 35 : 345 349, 1991. 